\title{
EVALUASI PENERAPAN STANDAR AKUNTANSI KEUANGAN KOPERASI PADA KOPERASI PEGAWAI REPUBLIK INDONESIA "TEHNOLOGIA" SMKN-1 PALANGKA RAYA
}

\author{
Evaluation of The Application of Special Standars of Cooperative Accounting on \\ Cooperative Employee Republic on Indonesia "Tehnologia" SMKN-1 Palangka Raya
}

\author{
*Endang Sri Suyati, lin Nurbudiyani, \& Santi Endriani \\ Economic Education Study Program, Universitas Muhammadiyah Palangkaraya, RTA Milono St. Km.1,5 \\ Palangka Raya, Indonesia \\ *e-mail : endangsuyati@yahoo.co.id
}

\begin{abstract}
ABSTRAK
Penelitian ini bertujuan untuk mengetahui bagaimana penerapan standar khusus akuntansi koperasi pada Koperasi Pegawai Republik Indonesia "Tehnologia" SMKN-1 Palangkaraya. Lokasi untuk melakukan penelitian ini bertempat di Koperasi Pegawai Republik Indonesia "Tehnologia" SMKN-1 Palangkaraya, di Jalan Tambun Bungai dan penelitian ini dilakukan pada bulan November 2017. Teknik pengumpulan data yang dipakai dalam penelitian ini adalah: Dokumentasi, yaitu teknik pengumpulan data dengan jalan mengumpulkan beberapa catatan, laporan manajemen dan lampiranlampiran yang diperoleh dari objek penelitian. Metode yang digunakan adalah deskriptif kualitatif, yaitu penelitian dengan maksud untuk mengumpulkan informasi mengenai status pada gejala yang ada, yaitu gejala menurut apa adanya pada penelitian yang dilakukan. Jenis atau metode penelitian ini tidak menggunakan rumus statistik, tetapi dengan menguraikan dan memberi argumentasi yang logis sehingga menghasilkan kesimpulan yang tepat. Kesimpulan dari penelitia ini adalah: 1) Penyusunan Laporan Keuangan oleh Bagian Administrasi yang berada di bawah koordinir Manajer telah dilakukan dengan baik, 2) Hasil penyusunan Laporan Keuangan membutuhkan atau memerlukan beberapa penyesuaian lebih maksimal terhadap PSAK No. 27 (edisi revisi 1998) tentang perkoperasian, dan 3) Laporan Promisi Ekonomi Anggata yang merupakan salah satu bentuk Laporan Keuangan koperasi, belum dibuat oleh bagian administrasi dan keuangan, serta catatan atas laporan keuangan masih belum memberikan informasi yang memadai yang sesuai dengan PSAK No. 27 tentang perkoperasian.
\end{abstract}

Kata kunci: Penerapan Standar Khusus Akuntansi, Koperasi Pegawai Negeri Republik Indonesia Tehnologia

\begin{abstract}
This study aims to find out how the application of special standards of cooperative accounting on Cooperative Employee Republic of Indonesia "Tehnologia" SMKN-1 Palangkaraya. The location for this research took place at the Cooperative Employee of the Republic of Indonesia "Tehnologia" SMKN-1 Palangkaraya, on Tambun Bungai Street and this study was conducted in November 2017. Data collection techniques used in this study are: Documentation, namely data collection techniques by collecting some records, management reports and attachments obtained from the object of research. The method used is descriptive qualitative, that is research with the intention to collect information about the status of existing symptoms, ie symptoms according to what is in the research undertaken. This type or method of study does not use statistical formulas, but by elaborating and giving a logical argument to produce the right conclusions. The conclusions of this research are: 1) Preparation of Financial Statement by Administration Section under Manager's coordination has been done well, 2) The result of preparation of Financial Statement require or needed some more maximal adjustment to PSAK No. 27 (1998 revised edition) about cooperatives. (3) The Member Economic Promotion Report, which is one form of the Cooperative Financial Statement, has not been made by the administration and finance department, and the notes to the financial statements have not provided sufficient information in accordance with PSAK No. 27 about cooperatives.
\end{abstract}

Keywords: Application of Acounting Standars, Tehnologia Cooperative Employee Republic Indonesia 


\section{PENDAHULUAN}

Sebagai satu-satunya organisasi yang sah dalam mengeluarkan Standar Akuntansi Keuangan (SAK), Ikatan Akuntansi Indonesia (IAI) secara langsung maupun tidak langsung memiliki peran yang besar dakam mengembangkan koperasi. Salah satu wujud peran serta tersebut adalah dalam bentuk kerja sama dengan Departemen Koperasi untuk mengeluarkan SAK untuk koperasi. Pengeluaran standar ini didasarkan pada kenyataan bahwa koperasi merupakan bentuk Badan Usaha yang memiliki karakteristik yang berbeda dengan badan-badan usaha lainnya. Kemudian dengan melihat perkembangan koperasi yang sangat pesat pada tahun 1987, sehingga sangat dimungkinkan untuk diterapkan standar akuntansi khusus tersebut. Hal ini mengisyaratkan adanya kewajiban bagi pihak pengurus dan pengelola koperasi untuk mengetahui dan memahami standar akuntansi tersebut dalam pelaporan keuangannya.

Seperti telah diketahui bahwa laporan keuangan merupakan salah satu sumber informasi yang sangat penting untuk menilai hasil pengelolaan koperasi, disamping sebagai alat pertanggungjawaban pengurus kepada anggotanya. Maka laporan keuangan koperasi harus disusun untuk dilaporkan berdasarkan standar akuntansi keuangan yang diberikan oleh Ikatan Akunatnsi Indonesia. Dan pengelolaan koperasi ini tentunya dilakukan dengan tuntunan pengelolaan koperasi yang sesuai dengan peraturan yang dikeluarkan oleh pemerintah melalui Departemen Koperasi. Salah satu alat manajemen yang sangat berpengaruh dalam menetapkan kebijakan usaha adalah akuntansi. Sehingga dalam penelitian ini kami ingin mengetahui sejauh mana kesesuaian antara Standar Akuntansi Koperasi yang telah ditetapkan dengan pelaksanaan akuntansi yang telah dilakukan oleh pengelola koperasi. Untuk itu perlu diadakan penelitian yangmengkaji hal itu yang sekaligus bisa sebagai program evaluasi.

Rapat anggota merupakan pemegang kekuasaan tertinggi dalam koperasi. Hal ini mengandung pengertian bahwa segala keputusan yang sifatnya mendasari mengenai kebijakan pengembangan aktifitas koperasi ditentukan oleh anggota yang disampaikan melalui frorum rapat anggota, setiap anggota mempunyai hak yang sama dalam mengeluarkan pendapatnya. Penyelenggaraan rapat anggota sekurang-kurangnya sekali dalam setahun. Jenis rapat anggota yang ada dalam koperasi KPRI TEHNOLOGIA adalah: a) Rapat Anggota Tahunan (RAT), yaitu rapat anggota yang diselenggarakan Akhir Tahun Buku. Diadakan oleh Pengurus dan Pengawas yang dihadiri oleh anggota. Rapat Anggota Tahunan ini mengesahkan laporan pertanggungjawaban Pengurus dan Pengawas, pembagian Sisa Hasil Usaha (SHU), pemilihan anggota Pengurus dan Pengawas, b) Rapat Anggota Khusus (RAK), yaitu rapat anggota yang diadakan untuk tujuan khusus seperti menetapkan kebijaksanaan umum dibidang organisasi, manajemen dan usaha koperasi untuk satu tahun untuk berikutnya. Serta untuk menetapkan RAPB koperasi dan perubahan Anggaran Dasar dan Anggaran Rumah Tangga koperasi, dan c) Rapat Anggara Luar Biasa, yaitu rapat anggaran diadakan untuk menetapkan penggabungan atau pembagian atau peleburan atau pembubaran koperasi atau apabila keadaan mengharuskan adanya keputusan segera yang wewenangnya ada pada rapat anggota. Maka 
dapat diadakan Rapat Anggota Luar Biasa dapat dilaksanakan permintaan tertulis 1//10 dari jumlah anggaran, Pengurus dan Pengawas.

Kekuasaan yang dimiliki oleh pengurus koperasi berada dibawah kekuasaan rapat 6 anggota. Pengurus hanya merupakan pemegang mandat yang dipilih, diangkat serta diberhentikan oleh anggota. Pengurus harus membuat kebijakan yang tidak menyimpang dari Anggaran Dasar dan Anggaran Rumah Tangga dan hasil keputusan rapat anggota lainnya dan pada akhir masa jabatannya yang harus mempertanggungjawabkan hasil kerja pada anggota.Secara umum, tugas utama pengurus Koperasi KPRI TEHNOLOGIA adalah memimpin koperasi, melakukan segala perbuatan hukum dan atas nama koperasi, serta mewakili koperasi baik di dalam maupun di luar pengadilan.

Pengurus dipilih dari anggota dan masa jabatan pengurus dan pengawas satu periode adalah dua tahun, dan setelah masa jabatannya berakhir dapat dipilih kembali. Unsur-unsur Pengurus Koperasi terdiri atas: Pengawas, Ketua, Sekretaris, dan Bendahara. Anggota koperasi yang dapat dipilih menjadi pengurus adalah yang memenuhi persyaratan sebagai berikut: 1) mempunyai sifat jujur dan ketrampilan kerja, 2) mempunyai pengetahuan tentang koperasian, dan 3) mempunyai rasa disiplin dan tanggung jawab atas jalan kegiatan usaha koperasi.

Pengurus bertugas: 1) menyelenggarakan rapat anggota, 2) menyelenggarakan pembinaan organisasi, 3) mewakili koperasi di dalam dan di luar pengadilan, 4) mengelola koperasi dan usahanya, 5) mengajukan rancangan rencana kerja dan Rencana Anggaran Pendapatan dan Belanja Koperasi, 6) mengajukan laporan keuangan dan pertanggungjawaban pelaksanaan tugas, 7) menyelenggarakan pembukuan secara tertib, dan 8) memelihara Daftar Buku Anggota, Daftar Buku Pengurus, dan Daftar Buku Pengawas. sedangkan pengurus berwenang: 1) menentukan kebijakan koperasi sesuai dengan Keputusan Rapat Anggota, dan 2) memutuskan penerimaan dan penolakan anggota baru secara pemberhentian anggota sesuai dengan ketentuan dalam Anggaran Dasar.

Tugas dan wewenang masing-masing komponen pengurus sebagai berikut:

Ketua, memiliki tanggung jawab baik ke dalam maupun keluar organisasi dengan uraian tugas selengkapnya sebagai berikut: 1) memimpin Koperasi dan mengkoordinasikan kegiatan seluruh anggota Pengurus, 2) mewakili Koperasi di dalam dan diluar pengadilan, dan 3) melaksanakan kegiatan perbuatan sesuai dengan Keputusan Rapat anggota dan Rapat Pengurus. Adapun wewenang dari Ketua adalah sebagai berikut: 1) menentukan kebijaksanaan dalam mengambil keputusan, 2) menandatangani surat-surat dan perjanjian bersama Sekretaris dan Bendahara, dan 3) ketua bertanggung jawab kepada Rapat Anggota.

Sekretaris: sebagai penanggungjawab adminitrasi koperasi uraian tugasnya adalah: 1) bertanggung jawab kegiatan administrasi dan perkantoran, 2) mengusahakan kelengkapan organisasi, 3) mengatur jalannya perkantoran, 4) menghimpun dan menyusun laporan kegiatan bersama bendahara dan pengawas, dan 5) menyusun rancangan rencana program kerja organisasi. Sedangkan sekretaris berwenang: 1) mengambil keputusan dibidang kesektariatan, dan 2) 
menetapkan pelaksanaan surat-surat bersama ketua.

Bendahara: pada dasarnya tugas pokok bendahara adalah mengurus kekayaan dan keuangan koperasi, antara lain: 1) bertanggung jawab masalah keuangan koperasi, 2) mengatur jalannya pembukuan keuangan, 3) menyusun anggaran setiap bulan, 4) mengawasi penerimaan dan pengeluaran uang, 5) menyusun rencana anggaran dan pendapatan koperasi, 6) menyusun laporan keuangan, dan 8) mengendalikan anggaran. Sedangkan Bendahara berwenang: 1) mengambil keputusan dibidang pengelolaan keuangan dan usaha, dan 2) bersama dengan ketua menandatangani surat yang berhubungan dengan bidang keuangan dan usaha.

Badan Pengawas: uraian tugas pengawas adalah: 1) melakukan pengawas terhadap pelaksanaan kebijakan pengurus menyangkut pengelolaan koperasi, baik yang menyangkut aspek organisasi maupun aspek usaha, 2) meneliti catatan yang pada koperasi, dan 3) membuat laporan tertulis tentang hasil pengawasan.

Tiap-tiap badan usaha memiliki beberapa ciri-ciri tersendiri, atau dengan kata lain ada krietria tertentu yang mendasari dalam pengelompokan bentuk usaha tersebut, kriteria tersebut antara lain berupa karakteristik. Badan usaha koperasi mempunyai beberapa karakteristik yang berbeda dengan badan usaha lain. Adapun karakteristik tersebut adalah sebagai berikut:

1. Koperasi Indonesia adalah Organisasi ekonomi rakyat berwatak sosial, beranggotakan orangorang atau badan hukum koperasi yang merupakan usaha bersama berdasarkan asas kekeluargaan.
2. Tujuan utama koperasi Indonesia adalah mengembangkan kesejahteraan anggota pada khususnya, dan masyarakat pada umumnya. Koperasi Indonesia adalah perkumpulan orangorang bukan bukan kumpulan modal, sehingga laba bukan merupakan ukuran utama kesejahteraan anggota. Manfaat yang diterima anggota lebih utama dari pada laba. Meskipun demikian harus diusahakan agar koperasi tidak menderita rugi. Tujuan ini dicapai dengan karya dan jasa yang disumbangkan oleh masingmasing anggota.

3. Keanggotaan koperasi indonesia sukarela dan didasarkan atas kepentingan bersama sebagai pelaku ekonomi. Melalui koperasi, para anggota ikut secara aktif, memperbaiki kehidupan dan kehidupan masyarakat melalui karya dan jasa yang disumbangkan. Dalam usahanya, koperasi akan lebih menekankan pada pelayanan terhadap kepentingan anggota, baik lebih banyak dilakukan kepada anggota dibandingkan dengan pihak luar, oleh karena itu anggota dalam koperasi bertindak sebagai pemilik sekaligus pelanggan.

4. Kegiatan koperasi dilakukan dalam suatu sistem jaringan koperasi. Dalam banyak hal terdapat keterkaitan yang erat antara anggota dengan anggota, koperasi dengan koperasi yang lainnya.

5. Koperasi yang didirikan oleh orang-orang atau badan-badan hukum koperasi adalah kesatuan usaha yang terpisah dan merupakan badan hukum yang berdiri sendiri, sesuai dengan kebutuhan dan untuk maksud-maksud efisiensi, koperasi dapat memusatkan diri menjadi koperasi pusat atau skunder, disamping itu untuk tujuan ekonomi koperasi dari berbagai 
jenis dapat mendirikan koperasi jenis lain. Pemusatan atau pendirian koperasi lain ini dilakukan dengan membentuk badan hukum koperasi tersendiri. Hubungan kepemilikan yang terdapat dalam koperasi yang mengadakan pemusatan atau mendirikan koperasi jenis lain tersebut di atas tidak mengakibatkan timbulnya satu kesatuan ekonomi dalam pengertian akuntansi.

6. Dalam menjalankan usahanya koperasi dapat mendirikan dan memiliki perusahaan atau unitunit usaha yang langsung berada dibawah tanggung jawab kepengawasan koperasi yang bersangkutan. Perusahaan dan unit-unit usaha tersebut di atas merupakan satu kesatuan dan dibawah satu pengelolaan dengan koperasi yang mendirikannya. Untuk perusahaan atau unit-unit usaha tadi tidak diperlukan badan hukum koperasi tersendiri. Koperasi beserta perusahaan atau unit-unit usaha yang memilikinya merupakan satu kesatuan akuntansi.

7. Koperasi dikelola oleh pengurus yang dipilih dari dan oleh anggotanya dalam satu rapat anggota. Dalam hal-hal tertentu anggota pengurus koperasi dapat berasal dari bukan anggota koperasi, dengan ketentuan, jumlahnya tidak melebihi sepertiga dari jumlah pengurus. Tugas dan kewajiban pengurus adalah memimpin organisasi dan usaha koperasi serta mewakilinya dimuka dan diluar pengadilan.

8. Manajemen koperasi dilakukan secara terbuka terutama untuk anggotanya. Keterbukaan dalam hal ini tidak boleh diartikan bahwa koperasi harus mengungkapkan semua informasi. Pengungkapan informasi-informasi yang berakibat merugikan koperasi itu sendiri, misalnya rumus-rumus kimia atau proses produksi, tidak termasuk dalam konsep keterbukaan manajemen dititik beratkan pada pelaksanaan fungsi pertanggung jawaban dengan baik oleh pengurus koperasi.

9. Dalam melakukan usahanya koperasi mengikuti hukum-hukum ekonomi yang rasional dan prinsip-prinsip ekonomi perusahaan termasuk prinsip efisiensi usaha.

10.Sesuai pasal 37 Undang-undang No. 12 Tahun 1967, pemerintah berkewajiban untuk memberikan bimbingan, pengarahan, pengawasan dan perlindungan terhadap fasilitas-fasilitas koperasi, dengan tujuan mendorong kearah kemandirian, dalam kaitan ini banyak kegiatan usaha koperasi yang tidak dapat dilepaskan dari kebijaksanaan pemerintah.

Pelaporan keuangan mempunyai pengertian yang lebih luas dari laporan keuangan, tetapi laporan keuangan merupakan elemen yang utama dalam pelaporan keuangan. Adapun pelaporan keuangan koperasi mempunyai beberapa karakteristik yang berbeda dengan badan usaha lain yaitu:

1. Pengurus bertanggung jawab dan wajib melaporkan kepada rapat anggota segala sesuatu yang menyangkut tata kehidupan koperasi. Aspek keuangan merupakan salah satu dari aspek-aspek yang tercakup dalam tata kehidupan koperasi. Laporan keuangan koperasi merupakan bagian dari laporan pertanggungjawaban pengurus tentang kehidupan koperasi

2. Laporan keuangan koperasi juga merupakan bagian dari sistem pelaoran keuangan koperasi. Laporan keuangan koperasi lebih 
ditujukan kepada pihak-pihak diluar pengurus koperasi dan tidak dimaksudkan dalam pengendalian usaha.

3. Pemakai utama laporan keuangan koperasi adalah para anggota koperasi itu sendiri beserta pejabat koperasi. Pemakai lainnya yang mempunyai kepentingan terhadap diantaranya adalah calon anggota, bank, kreditur dan kantor pajak.

4. Kepentingan pemakai utama laporan keuangan koperasi terutama adalah:

a. Menilai pertanggungjawaban pengurus

b. Menilai prestasi pengurus

c. Menilai manfaat yang diberikan koperasi terhadap anggotanya

d. Sebagai bahan pertimbangan untuk menentukan jumlah sumber daya, karya dan jasa yang akan diberikan kepada koperasi

5. Modal koperasi terdiri dari simpanan, pinjaman, penyisihan dari sisa hasil usaha termasuk cadangan serta sumber lain. Simpanan anggota dalam koperasi terdiri dari simpanan pokok, simpanan wajib, simpanan sukarela. Simpanan sukarela dapat berasal dari bukan anggota. Cadangan dalam dikmaksudkan untuk memupuk modal koperasi dan untuk menutup kerugian koperasi. Cadangan bukan milik anggota koperasi dan tidak boleh dibagikan kepada anggota walaupun pada waktu pembubaran. Istilah permodalan koperasi dengan demikian tidak hanya mencakupi modal yang disetorkan oleh anggota. Permodalan dalam meliputi seluruh pembelanjaan dalam koperasi yang dapat bersifat permanen atau sementara. Pihak-pihak yang mempunyai klaim terhadap sumber daya koperasi terdiri dari kreditur, anggota pemilik dan badan usaha koperasi itu sendiri. Struktur klaim yang demikian menunjukkan bahwa koperasi mempunyai eksistensi tersendiri terpisah dengan anggotanya.

6. Pendapatan koperasi yang diperoleh dalam satu tahun buku dikurangi denagn beban operasional, termasuk beban penyusutan dan kerugian piutang dari tahun-tahun buku yang bersangkutan disebut sisa hasil usaha. Sesuai dengan karakteristik koperasi sisa hasil usaha berasala dari hasil usaha yang diselenggarakan untuk anggota dan juga bukan anggota. Sisa hasil usaha pada koperasi bukan merupakan satu-satunya alat pengukur bagi manfaat keanggotaan koperasi dan prestasi pengurus. Sisa hasil usaha dengan demikian, merupaha hasil dari aturan dan prosedur akuntansi yang diterapkan dalam koperasi dan mencerminkan perubahan kekayaan bersih yang dimiliki oleh anggota dan koperasi itu sendiri, yang berasal dari transaksi, kejadian atau keadaan ekonomi yang timbul dari kegiatan usaha.

7. Keanggotaan pada koperasi tidak dapat dipindah tangankan dengan dalih apapun. Kewajiban anggota untuk kerugian yang diderita oleh koperasi baik yang timbul pada penutupan tahun buku maupun pada saat pembubaran dapat ditetapkan terbatas atau tidak terbatas, maka kerugian harga dapat dibebankan pada kekayaan koperasi (dalam bentuk cadangan yang telah dipupuk) dan kepada anggota sebesar sejumlah tanggungan yang ditetapkan dalam anggaran dasar. Dalam kaitan ini sisa hasil usaha bukan merupakan perubahan kekayaan dari anggota.

8. Laporan keuangan merupakan ringkasan dari suatu proses transaksi keuangan yang terjadi 
selama satu tahun buku tertentu. Laporan keuangan yang dibuat oleh manajemen selain mempunyai tujuan untuk mempertanggungjawabkan tugas-tugas yang dibebankan kepadanya oleh pengurus atau anggota juga sebagai alat bantu dalam pengambilan keputusan manajemen. Laporan keuangan yang disusun oleh manajemen terdiri dari: 1) neraca, 2) perhitungan sisa hasil usaha, 3) laporan arus kas, 4) perubahan promosi ekonomi anggota, dan 5) catatan atas laporan keuangan

Adapun karakteristik laporan keuangan koperasi adalah:

1. Laporan keuangan merupakan bagian dari pertanggungjawaban pengurus pada para anggotanya di dalam rapat anggota tahunan

2. Laporan keuangan biasanya meliputi Neraca, Perhitungan Laba Rugi, Laporan Arus Kas, Laporan Promosi Ekonomi Anggota, catatan Atas Laporan Keuangan yang penyajiannya dilakukan secara komparatif

3. Sesuai dengan posisi koperasi sebagai bagian dari sistem jaringan koperasi, maka beberapa akunatau istilah yang sama akan muncul baik pada kelompok aktiva maupun kewajiban atau kekayaan bersih

4. Perhitungan Laba Rugi menyajikan hasil akhir yang disebut Sisa Hasil Usaha (SHU). Sisa hasil usaha dapat berasal dari anggota dan non anggota. Sisa hasil usaha yang dibagikan pada anggota harus berasal dari anggota. Pada rapat anggota tahunan hasil usaha ini diputuskan untuk dibagi sesuai dengan ketentuan yang ada di Undang-undang anggaran dasar. Komponen pembagian sisa hasil usaha sesuai dengan Undang-undang adalah sebagai berikut: a. Sisa Hasil Usaha yang berasal dari anggota meliputi: Cadangan Koperasi, Anggota sebanding dengan jasa yang diberikan, Dana Pengurus, Dana Pegawai/Karyawan, Dana Pendidikan Koperasi, Dana Sosial, Dana Pembangunan Daerah Kerja.

b. Sisa Hasil Usaha yang berasal dari bukan anggota meliputi: Cadangan Koperasi, Dana Pengurus, Dana Pegawai/Karyawan, Dana Pendidikan Koperasi, Dana Sosial, Dana Pembangunan Daerah Kerja

c. Komponen-komponen tersebut selama belum dicairkan, disajikan dalam kelompok kewajiban lancar pada neraca, sedangkan cadangan koperasi merupakan bagian sisa hasil usaha yang tidak dibagi dan dapat menutup kerugian

5. Dengan adanya konsep sistem jaringan koperasi atau aturan dari pemerintah, maka terdapat aktiva atau sumber daya yang dimiliki koperasi tetapi dapat dikuasainya dan sebaliknya terdapat aktiva atau sumber daya yang dikuasainya tetapi tidak dimilikinya.

6. Laporan keuangan koperasi merupakan laporan keuangan kosolidasi dari unit-unit usaha yang ada dalam koperasi.

Standar akuntansi merupakan konsep dasar, prinsip, prosedur, metode dan teknik akuntansi yang merupakan norma di dalam praktik penyususnan laporan keuangan. Karena koperasi memiliki karakteritik yang berbeda dengan badan usaha yang lain, maka Ikatan Akuntansi Indonesia (IAI) bekerjasama dengan Departemen Koperasi dalam menyusun standar akuntansi untuk koperasi. Wujud kerjasama ini tertuang dalam Surat Keputusan Bersama Direktur Jendral Bina Lembaga Koperasi dengan ketua Ikatan Akuntansi 
Indonesia

(IAI)

No.17/SKB/BLK/VII/87-

01/KEP/VII/87 Tanggal 16 Juli 1987, yaitu standar khusus akuntansi untuk koperasi. Pada tanggal 1921 September 1994 diadakan konggres VII Ikatan Akuntansi Indonesia (IAI) di bandung, yang menghasilkan keputusan bahwa untuk menghindari kesalahpahaman dan agar sesuai dengan makna, maka sebutan Prinsip Akuntansi Indonesia diganti dengan Standar Akuntansi Keuangan. Standar Akuntansi Keuangan untuk koperasi yang ada di dalam Prinsip Akuntansi Indonesia terdapat pernyataan nomor 3 diganti dengan Standar Akuntansi Keuangan pernyataan nomor 27, dengan sebutan Standar Akuntansi Keuangan koperasi.

Dengan adanya standar akuntansi ini diharapkan gerakan perkoperasian di Indonesia dapat lebih berkembang. Standar Akuntansi khusus koperasi sangat diperlukan sebagai acuan penyusunan laporan keuangan sebagai informasi keuangan bagi pengurus dan pihak luar manajemen koperasi.

Bentuk-bentuk laporan keuangan yang disusun oleh koperasi pada akhir periode yang telah ditetapkan dalam standar akuntansi keuangan adalah: a) Neraca, b) Perhitungan Sisa Hasil Usaha, c) Laporan Arus Kas, d) Laporan Promosi Ekonomi Anggota, dan e) Catatan Atas Laporan Keuangan

\section{METODOLOGI}

Lokasi untuk melakukan penelitian ini bertempat di Koperasi Pegawai Republik Indonesia

"Tehnologia" SMKN-1 Palangkaraya, di Jalan Tambun Bungai dan penelitian ini dilakukan pada bulan November 2017. Penelitian ini dilakukan di Koperasi Pegawai Republik Indonesia
"Tehnologia" SMKN-1 Palangkaraya dengan pertimbangan:

1. Ketersediaan dan kemudahan memperoleh laporan keuangan yang dibutuhkan sebagai informasi dasar dalam penyelesaian penelitian.

2. Keterbatasan waktu, biaya dan tenaga dalam malakukan penelitian.

3. Koperasi yang beranggotakan guru dengan modal yang lumayan besar dan produktif.

Suatu penelitian dilakukan untuk memperoleh kebenaran atau pembuktian suatu kebenaran terhadap suatu objek permasalahan untuk mendukung penelitian tersebut, sumber data yang diperoleh melalui data sekunder atau yang terkumpul seharusnya yang benar-benar dapat dijamin kebenarannya. Selain itu data yang terkumpul harus relevan dengan permasalahan yang sedang dihadapi.

Teknik pengumpulan data yang dipakai dalam penelitian ini adalah: Dokumentasi, yaitu teknik pengumpulan data dengan jalan mengumpulkan beberapa catatan, laporan manajemen dan lampiran-lampiran yang diperoleh dari objek penelitian.

Analisis data merupakan hal yang terpenting, karena merupakan hasil dari sebuah analisis data dalam penelitian yang merupakan pendapat. Dalam penelitian ini metode yang digunakan adalah deskriptif kualitatif, yaitu penelitian dengan maksud untuk mengumpulkan informasi mengenai status pada gejala yang ada, yaitu gejala menurut apa adanya pada penelitian yang dilakukan.

Jenis atau metode penelitian ini tidak menggunakan rumus statistik, tetapi dengan menguraikan dan memberi argumentasi yang logis sehingga menghasilkan kesimpulan yang tepat, dengan cara: 
1. Membandingkan antara Standar Akuntansi Keuangan Koperasi dengan pelaksanaan yang telah diterapkan oleh Koperasi Pegawai Republik Indonesia "Tehnologia" SMKN-1 Palangkaraya pada laporan keuangan yang telah dibuat.

2. Membandingkan hasil pelaksanaan aturan Standar Akuntasi Keuangan, antara komponen laporan keuangan yang telah disusun oleh Koperasi Pegawai Republik Indonesia "Tehnologia" SMKN-1 Palangkaraya.

\section{HASIL DAN PEMBAHASAN}

KPRI "Tehnologia" adalah koperasi Primer yang anggotanya terdiri dari Guru-guru dan Karyawan SMK Negeri 1 Palangka Raya, yang mempunyai kesamaan aktivitas, kepentingan, tujuan dan kebutuhan ekonomi (sesuai dengan PP tahun 1959) yang berdiri sejak tanggal 25 September 1981 dan terdaftar pada kantor wilayah Dep Koperasi di Palangka Raya tanggal 20 September 1984. Dalam menjalankan usahanya KPRI Tehnologia sudah mengalami perkembangan yang sangat baik. Sehingga dalam beberapa tahun belakangan ini beberapa anggota yang aktif merasakan manfaatnya.

Rapat Anggota Tahun (RAT) yaitu rapat anggota yang diselenggarakan tiap akhir tahun buku, merupakan sarana bagi pengurus dan anggota untuk mengevaluasi sejauh mana keberhasilan usaha yang djalankan selama satu tahun buku dan sebagai acuan untuk merencanakan Program Kerja tahun buku berikutnya serta menesahkan laporan pertanggungjawaban Pengurus, pembagian Sisa Hasil Usaha (SHU).

Struktur Organisasi "Tehnologia” SMK Negeri 1 Palangka Raya meliputi:

\section{Keanggotaan}

Jumlah anggota Koperasi "Tehnologia" SMK Negeri 1 Palangka Raya sampai dengan 31 Desember 2016 seluruhnya adalah sebanyak 128 (seratus dua puluh delapan) orang, dimana pada tahun buku 2015 jumlah anggota berjumlah 127 orang, selama tahun 2016 ada sebanyak 4 orang anggota yang keluar karena pension dan penambahan anggota baru sebanyak: 5 orang. Anggota koperasi ini pada umumnya merupakan guru-guru dan Tata Usaha SMK Negeri 1 Palangka Raya dan sebagian adalah guru-guru yang mutasi tugas ke tempat lain.

\section{Pengurusan}

Komposisi pengurus KPRI Tehnologia SMK Negeri 1 Palangka Raya periode 2014-2016 hasil Rapat Anggota Tahunan Tahun Buku 2013 dengan komposisi sebagai berikut:

a. Pembina: 1. Dinas Perindag dan Koperasi kota Palangka Raya 2. Kepala SMKN 1 Palangka Raya

b. Pengurus: Ketua : Berlina, M.Pd

Sekretaris : Sri Wijiati S.,S.Pd

Bendahara: Dra. Hj. Fakhriah

c. Unit Simpan Pinjam:

Bendahara : Sri Wijiati S.,S.Pd

d. Unit Barang Sekunder:

Bendahara : Peni Oktarianti, M.Pd

\section{Permodalan}

Dalam rangka meningkatkan usaha KPRI Tehnoologia SMK Negeri 1 Palangka Raya untuk kesejahteraan anggotanya dilakukan usaha-usaha penggalangan dana melalui beberapa sumber, antara lain adalah: 
a. Simpanan pokok anggota per orang dibebankan sebesar Rp. 50.000,-

b. Simpanan wajib anggota per orang per bulan sebesar Rp. 200.000,-. Simpanan pokok anggota sudah mencapai arap. 6.400.000,- dan simpanan wajib RP. 1.509.006.029,-Jumlah keseluruhan dari simpanan pokok dan simpanan wajib $\mathrm{Rp}$. 1.515.406.029,--

c. Simpanan anggota dari dana cadangan $\mathrm{Rp}$. 167.089.273,-

Jenis-jenis Usaha yang dilaksanakan pada KPRI Tehnologia SMK Negeri 1 Palangka Raya pada tahun buku 2016 meliputi 5 (lima) unit usaha, yaitu sebagai berikut:

1. Usaha Simpan Pinjam (USP)

Usaha simpan pinjam adalah salah satu unit usaha pada KPRI Tehnologia Palangka Raya dengan bunga pinjaman sebesar $2.0 \%$ per bulan. Volume pinjaman hingga Desember 2016 adalah sebesar Rp. 3.198.596.530,- Dari hasil usaha yang dilaksanakan selama satu tahun buku 2016. Unit simpan pinjam telah mendapatkan sisa hasil usaha (SHU) sebesar Rp. 514.740.025,-.

\section{Usaha Barang Sekunder}

Usaha barang sekunder adalah salah satu unit usaha pada KPRI Tehnologia Palangka Raya dengan menyediakan barang-barang rumah tangga bagi anggota. Volume pinjaman hingga Desember 2016 adalah sebesar Rp. 76.617.050,- Dari hasil usaha yang dilaksanakan selama satu tahun yaitu tahun buku 2016, unit barang sekunder telah mendapatkan siswa hasil usaha (SHU) sebesar Rp. 17.724.400,-
3. Usaha Sewa Toko dan Kantin Usaha toko adalah usaha langsung dikelola oleh koperasi. Adapun took yang disewakan berjumlah 2 buah dan 9 buah kantin. Hasil sewa took dan kantin pada tahun buku 2016 ini adalah Rp. 78.000.000,- Dari hasil sewa ini dilakukan rehabilitasi dan pemasangan token listrik dan melengkapi fasilitas kantin, sehingga sisa hasil usah (SHU) sebesar Rp. 1.000.000,--

4. Usaha baju dan atribut sekolah

Pada tahun 2016, koperasi dipercaya pihak sekolah untuk mengelola baju 2 steel (pasang) yaitu baju koprs dan baju praktek dan atribut sekolah. Dari hasil usaha tersebut diperoleh sisa hasil usaha (SHU) sebesar Rp. 46.897.000,-.

5. Usaha Pengkavlingan tanah

Usaha pengkavlingan tanah ini dimulai bulan November 2014, saat ini sudah ada mendapatkan keuntungan sebesar Rp. 10.425.000,-.

\section{KESIMPULAN}

Penyusunan Laporan Keuangan oleh Bagian Administrasi yang berada di bawah koordinir Manajer telah dilakukan dengan baik. Hasil penyusunan Laporan Keuangan pada KPRI TEKNOLOGIA SMKN 1 Palangka Raya membutuhkan atau memerlukan beberapa penyesuaian lebih maksimal terhadap PSAK No. 27 (edisi revisi 1998) tentang perkoperasian. Laporan Promisi Ekonomi Anggata yang merupakan salah satu bentuk Laporan Keuangan koperasi, belum dibuat oleh bagian administrasi dan keuangan, serta catatan atas laporan keuangan masih belum memberikan informasi 
yang memadai yang sesuai dengan PSAK No. 27 tentang perkoperasian.

\section{DAFTAR PUSTAKA}

Al-Haryono. 1996. Pengantar Akuntansi. Yogjakarta: Universitas Gajah Mada.

Baridwan, Z. 1990. Intermediate accounting. Edisi 6. Yogjakarta: Universitas Gajah Mada, BPFE.

Departemen Koperasi Republik Indonesia. 1991. Pedoman Akuntansi Desa. Jakarta: Dirjen Bina Lembaga Koperasi.

Ikatan Akuntansi Indonesia. 1999. Standar Akuntansi Keuangan. Pernyataan No. 27.

Kusnadi. 1999. Pengantar Akuntansi Keuangan. Edisi 1, Malang: Brawijaya Press.

Lembaran Negara Republik Indonesia, UU RI No. 25 Tahun 1992, tentang Perkoperasian.

Machfudz, M. 1985. Akuntansi Intermediate. Yogyakarta: Liberty.

Wilson, J.D., \& Campbell, J.B. 1988. Controllership the Work of the Managerial Accountant. 3 Edition. John willey and Soon, Inc, New York. 